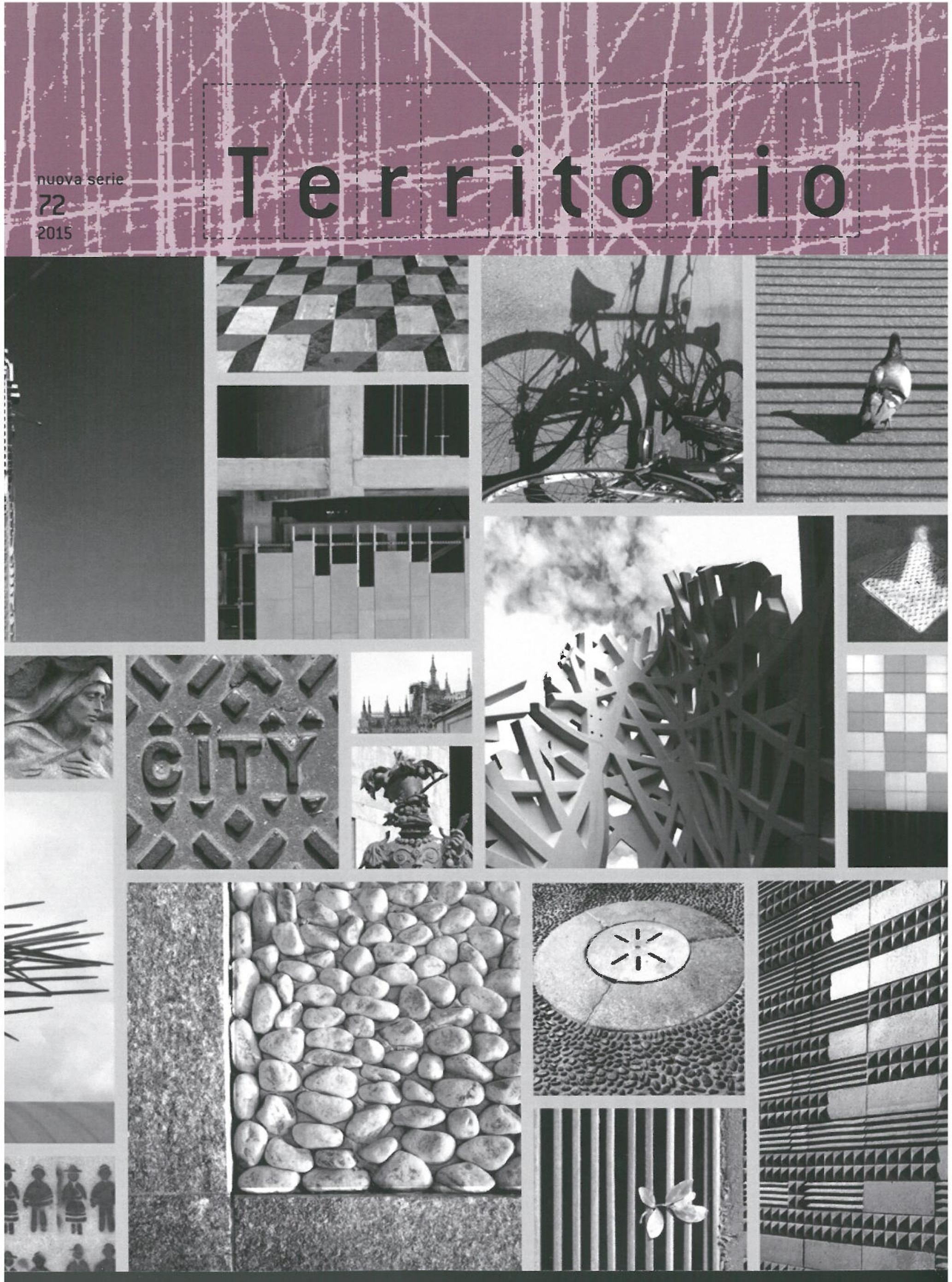


aperture

temi
7 Intimité, extimité, public. Riletture dello spazio pubblico Intimité, extimité, public. Re-readings of public space Cristina Bianchetti

18 In comune. Percorsi di ricerca per un nuovo progetto di prossimità nella città pubblica

In common. Research pathways towards a new kind of proximity-focused planning in the public city a cura di Sara Basso

21 Paesaggi pubblici/paesaggi comuni. Possesso. Appartenenza. Carattere

Public landscapes/common landscapes. Possession. Belonging. Character

Annalisa Metta

28 Spazi, usi, popolazioni. Tre dimensioni necessarie per attivare spazi comuni

Spaces, uses, populations. Three necessary dimensions for activating common spaces

Antonella Bruzzese

36 I cortili di San Siro a Milano. Un laboratorio di condivisione The San Siro courtyards in Milan. An experiment in sharing (scheda a cura di Gianfranco Orsenigo)

40 La terza via. Nuove regole per trasformare gli spazi aperti nei quartieri della città pubblica

The third way. New rules for transforming open spaces in public-city districts

Maria Livia Olivetti

47 Edificio 111 a Barcellona. Spazio di transizione e costruzione di una comunità di vicinato

Edificio 111 in Barcelona. Transitional space and constructing a neighbourhood community

(scheda a cura di Giuseppina Scavuzzo)

51 Comfort urbano. Tre direzioni di ricerca attorno ad un nuovo progetto di prossimità

Urban comfort. Three research directions around a new proximity-focused planning approach

Antonio di Campli

59 Nuove società e inerzia dello spazio aperto. Matera e gli esiti di un progetto riformista agro-urbano

New societies and inertia in open space. Matera and the outcomes of an agro-urban reform project Mariavaleria Mininni

67 La Martella a Matera. Da borgo rurale a periferia urbana? Matera's La Martella hamlet. From rural village to urban outskirts? (scheda a cura di Cristina Dicillo)

71 Lo spazio di mediazione come dispositivo di progetto per la riqualificazione dei quartieri Erp

Buffer space as a project tool for renewing public-housing districts

(scheda a cura di Cecilia Perna)

75 Ripensare la prossimità nella città pubblica. Strumenti per la ricomposizione degli spazi, oltre l'alloggio

Rethinking proximity in the public city. Tools for piecing spaces back together, besides housing Sara Basso 
progetti

spazio aperto

recensioni

avventure dello sguardo
83 Border/scapes. Borderlands and design studies in dialogue edited by Alice Buoli

85 Borderscaping: design pattems and practices on/across borderlands

Alice Buoli

95 Complexity and simultaneity. The border as spatial condition Marc Schoonderbeek

101 BorderScapes: redesigning the borderland Henk van Houtum and Mark Eker

108 Boundaryscapes: a digital and dynamic Atlas for collaborative planning in the Ciprus Green Line Anna Grichting

117 After Fadaiat: a conversation with Pablo de Soto (form edited by Alice Buoli)

120 1937-1948: Gio Ponti urbanista. Due progetti sull'ex scalo Sempione a Milano 1937-1948: Giò Ponti, town planner. Two designs for the disused Milan Porta Sempione railway station Stefano Guidarini

131 Cuore della Città e Urban Design: contraddizioni e ibridazioni nel Dopoguerra

Heart of the City and Urban Design: post-war contradictions and hybrid approaches

Leonardo Zuccaro Marchi

142 Complessità dell'abitare contemporaneo The complexity of contemporary living Raffaele Pugliese

151 Insights and reflections on Jane Jacobs' legacy. Toward a Jacobsian theory of the city Stefano Cozzolino

158 Demolizioni e ricostruzioni nella città storica in Cina: un matrimonio d'interesse tra tradizione e mercato Demolition and reconstruction in historic Chinese cities: a marriage of convenience between tradition and the market Giuseppe Cinà

161 Land cover changes and impact on ecosystems services. The case study of Rimini (Italy)

Elisa Morri, Giovanna Pezzi, Riccardo Santolini

177 Fabio Amato, Giovanni La Varra, Irene Amadio, Agostino Petrillo, Alessandro Coppola, Mario Fumagalli, Annalisa Colombino, Francesco Gastaldi

190 Juno Tani: «Frammenti di luogo» Juno Tani: «Fragments of place» a cura di Francesco Infussi

202 Abstract english summary 


\title{
BorderScapes: redesigning the borderland
}

\author{
Henk van Houtum" and Mark Eker**
}

* Radboud University Nijmegen, Nijmegen Centre for Border Research (Ncbr) and University of Bergamo

** Eindhoven University of Technology, Province of NoordHolland, Haarlem

(h.vanhoutum@fm.ru.nl, bureau@ekerschaap.nl)

Le frontiere interne dell'Unione Europea sono aperte da più di venti anni. Tuttavia, una visione spaziale coordinata per i paesaggi di frontiera europei è ancora da comporre. Le attuali procedure burocratiche di cooperazione e l'emergere di nuovi sentimenti nazionalistici sembrano essere oggi d'ostacolo a un'efficace cooperazione transfrontaliera. In questo saggio evidenziamo la necessità di un nuovo progetto per i paesaggi di frontiera. Riteniamo, infatti, che studiosi, artisti, architetti e film-makers potrebbero proporre insieme nuovi modi, più inclusivi, immaginativi e criticamente impegnati per ri-disegnare le frontiere. Tali argomentazioni sono basate su una nostra recente pubblicazione 'Borderland' in cui, partendo da un'analisi approfondita del confine tra Olanda, Belgio e Germania, è stato sviluppato un nuovo approccio progettuale e cartografico al paesaggio di frontiera

Parole chiave: borderscapes; progetto per i paesaggi di frontiera; scenari

\section{Introduction: borders as scapes}

When looking at the border regions of the European Union a striking observation can be made. After about two decades of experimenting with cross-border cooperation within the framework of Interreg in the European Union ${ }^{1}$, it can be ascertained that there is a general lack of power, courage or will to really make an integral design of the border regions siding next to each other. For many local and regional planners and governors the border is still seen as the end of a national planning zone and hence only simply understood as a barrier for European integration. But an integral spatial vision and visualisation for European border landscapes, within a common framework for cross-border spatial planning, is still missing. The ambiguity, the ambivalence, the interplay between here and there, the quietness, the interesting contrast is hardly seen as the beginning of a plan. Usually, the paradigm of the ' 80 's that the border is an obstacle, a barrier that impedes cross-border interaction, dominates. The conceptual richness that has been developed in most parts of the fields of border studies over the last decades or so (Paasi, 2005; Van Houtum et al., 2005; Wilson and Donnan, 2012) has not found its way into concrete regional planning and design. Also for the country where we live and work, the Netherlands, despite having one of the oldest cross-border regions in its domains, the Euregion, this observation holds. The Dutch have a long-standing tradition when it comes to landscape planning and design. But for the case of border regions, there is a remarkable lack of interest. That is a missed opportunity. For the regions themselves, but also for the further development of the debate in border studies. We argue here that there is need and a chance to take the term border landscape literally in the case of border regions. With this we mean, it is interesting to go back to what scape originally means, namely to shape, to create. As it was explained in a special issue of Agorà (Van Houtum and Spierings, 2012), entitled 'Borderscapes', scapes comes from the Dutch term 'Scheppen (to create) and the past tense of 'Scheppen' which is 'geschapen' (was created), and the Dutch term 'Landschap', which means something like a created land. This term was picked up in English and later was turned into landscape. Interestingly, recently, the Italian researcher Brambilla picked this up as well in her assessment of the critical potential of borderscapes (2014) and by Buoli ${ }^{2}$. And earlier, used and interpreted differently, Kumar Rajaram, and Grundy-Warr in 2007 also hinted at the potential of the hidden geographies of borderscapes. If 
we accept the idea that a border is a construct, a social design, which is common knowledge now in border studies, it means that there is also room to redesign a border and hence there is a possibility to tell another, more liberating narrative of the same border, one that goes beyond the existing narrative of the border being the end of a national planning zone.

\section{Division as an opportunity}

With the idea in mind to go back to the origins of the word Scapes, to see borders as scapes, as land to be developed and designed, we recently published the book «Borderland: atlas, essays and design" (Eker and Van Houtum, 2013). The main question was: what are the possibilities for a reinterpretation of borders as spaces to redesign and architecturally reshape, or in short, to see borders as spaces to create, as 'scapes'? The start of our research was to distinguish a strip of land $20 \mathrm{~km}$ on either side of the border with Germany and Belgium - the area referred to as the 'borderland'. The Dutch border landscape covers about $28 \%$ of the land area of the Netherlands. It has 5.8 million inhabitants, and with an average of 494 inhabitants per square kilometre it is more densely populated than the rest of the country ( 385 inhabitants per square kilometre).

The boundary we drew around the border landscape, to define our field of research, is an arbitrary one; it is just as much of a 'construct' or design as the national borders themselves.

Its purpose is simply to allow one to think and talk about the area as a whole, to make it manageable as a subject for investigation. The common characteristic shared by all the places in this zone is their location in relation to the centre of the Netherlands: as far away as possible. In this respect, this makes this part of the country peripheral, whereas in other respects some parts of it could be considered to be very central indeed. This makes the 'land border landscape' somewhat different from the 'sea border landscape', which is more uniform and which generally conjures up just one type of image. The border with the sea is a geomorphological border; it is not a result of agreements or conflicts with others. From a historical, social and spatial perspective, the land border is a multidimensional and complex construct. We interpret the ambiguity, two-sidedness and division that characterise the border zone as an opportunity to plan and design the area in a different way. The appreciation of border landscapes as landscapes of difference is growing worldwide, while the national traditions and practices underlying these differences at least in the EU are meant to slowly converge in a EU wide planning. And so national orientations are giving way to international ones and the EU is harmonising its legislation on numerous topics and seeks to eliminate regional disparities. The Borders as Scapes project is hence also a design study to investigate the development possibilities of the current Dutch border landscape in the context of this on-going European integration.

\section{Borderers}

Right from the very early experimental phases of this long project, already in 2004, the aspiration was to make a link between thinking and doing - translating the morphological presence of the border landscape into a meaningful new design - and it was the reason that brought together various disciplines in the research project. During the first excursion involving landscape architects, town planners, social geographers, artists and art historians, it became immediately apparent that these disciplines looked at the landscape in different ways. The social geographers and art historians, who can roughly be described as observers, took the landscape to be a result of constructs, processes and events, as an area where different groups of people live and work. The designers, the landscape architects and town planners, did that as well, but they perceived the landscape primarily as something that could be remodelled. They constantly thought in terms of relocating rows of trees and dikes, and restructuring areas. The realisation of such differences between disciplines fuelled a fruitful discourse in which the border and its landscape was continually reconsidered and recast. Interestingly, all the researchers involved in our research were initially clearly affected by a strong reflex, a hesitancy or diffidence about entering the imaginary space of the other and daring to think about it and reshape it. Perhaps this is key to the lack of inspiring border designs. We have arguably become too disciplined too tied to our own national space and too conditioned in thinking that there is only one design for a border, namely the current dominant one represented by fences or lines on maps. So, in the spirit of the philosopher Jacques Rancière, we worked towards becoming true 'borderers' (in German: Grenzgängers), writers and thinkers between and beyond disciplines and internal disciplination (De Boer, 2007). The figure of the Grenzgänger allows us to focus our attention on the role of interdisciplinary geopolitical narratives and practices, so essential when studying borderscapes. The Grenzgänger typically could be understood as an itinerant of the in-between spaces, a goer who trains his eye on the hidden or latent geographies and does not allow him/herself to be constrained by (urban) borders and monolithic interpretations of spaces (Brambilla and Van Houtum, 2012, p. 28).

\section{Cultural heritage and design}

The border landscape is considered as a landscape with a certain cultural heritage value - because of the presence of the border as a tangible and abstract fact, because of the activities and characteristics of the area inherent to its location, and because of the 150 years during which the current situation along the Dutch border was able to evolve. However, the term 'cultural heritage' may lead one to think that our intent was to encapsulate the 'unique and specific characteristics' of this landscape as a sort of museum piece to be conserved - to designate the border landscape with the purpose of fencing it off for preservation. If the border landscape, or parts of it, could be identified so unequivocally and precisely, we believe that only focusing on a strategy conserving it would not be a good idea. Rather, the border landscape is something that 'evolved' because for one reason or another it has been ignored, because the border was the 'limit of the plan area' or because it was where passage to the rest of the world had to be facilitated. Seldom has the border landscape been planned or designed in any meaningful way with the idea of making it a landscape itself. The question of how to do this and what interesting possibilities this opens up is what our study set out to investigate. 


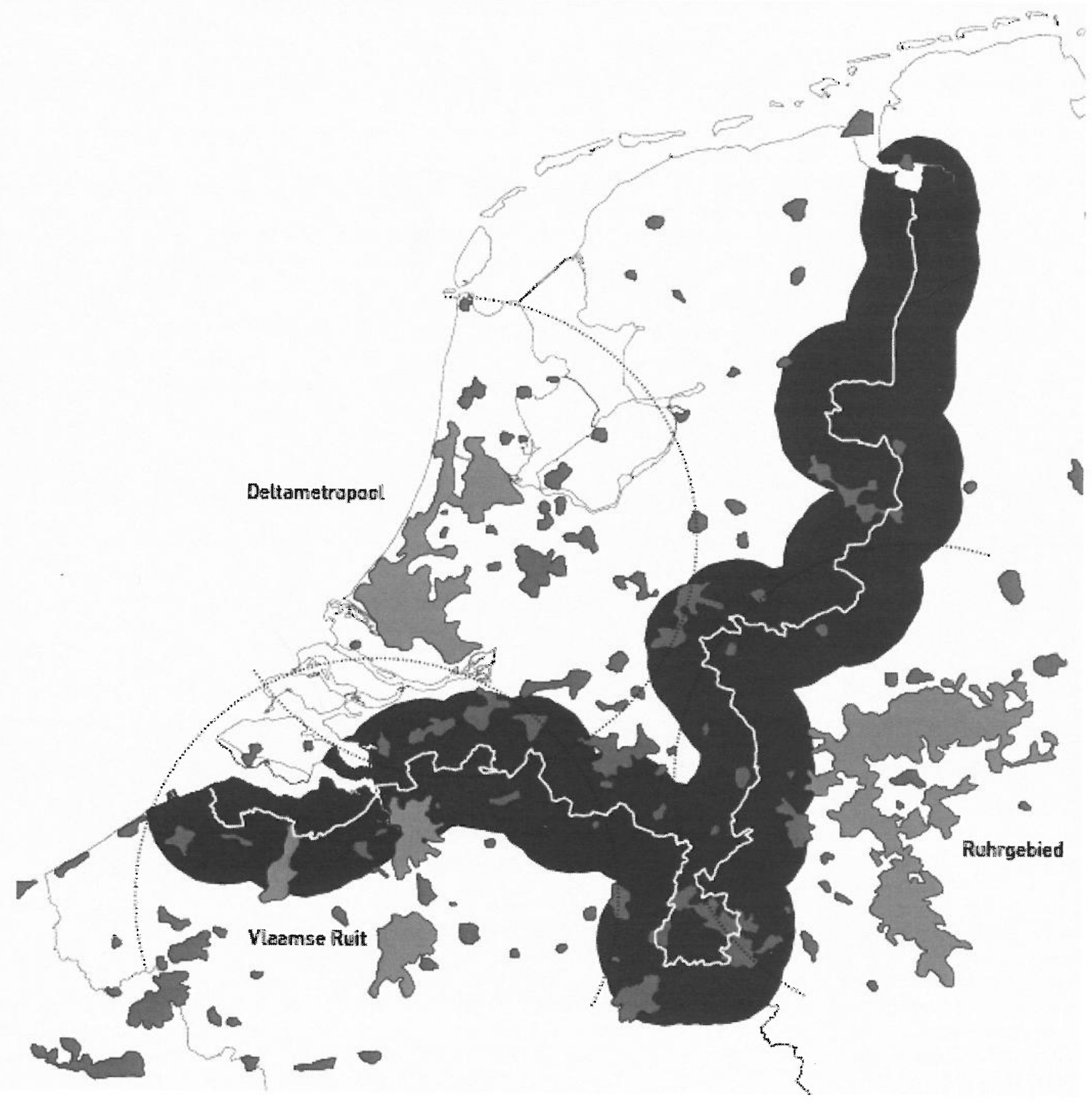




\section{Transition space}

Although we investigated the cultural heritage of the border landscape, we looked at it just as much as a non-landscape: as a transition space, a place that has been largely unnoticed. A place which, if you really wanted to preserve it, you would have to ask yourself whether it would not actually be better if it remained unnoticed. In this sense, this study can be seen as part of a wider growing interest in forgotten corners, nomans lands, transitional zones, hidden landscapes, white areas and deregulation - born of a realisation that the Netherlands has been planned to a great detail and that a lack of planning and leaving things alone may just provide some much needed freedom and room for manoeuvre. Discussion on this aspect within the working group led to the coining of the term 'dedesigning', or 'non-designing', and the inevitable question of whether this is actually possible, and how.

\section{Border as Janus}

In our final book we first described the present situation. The form, diversity and qualities of the border landscape were surveyed, and where possible visualised. Then, in the second part of the study, assuming that the border is a political construct, a design, we study the historical, existing and expected political interest in the border landscape. After this the book focused on the possibility of redesigning the borderland. Can one step out of the conventional way of thinking, can we steer a different course, and can we re-design? To inspire the search for new designs, we made use of the theoretical concept of the Janus face (Van Houtum, 2010a), implying a continuum of two different kinds of desires or, their reverse, fears. We explored these two opposite desires as tools for imaging two alternative future configurations for the border landscape. On the one hand there is a tendency to retreat behind the border, to close the door and hide away for the world outside. This tendency is what Deleuze and Guattari $(1972,1980)$ called 'paranoid' desire or what Nietzsche termed "Apollian desire» (1872). Within this desire to retreat, there is a tendency to long for a here and $w e$, a process of what was described earlier as «Bordering, Ordering and Othering” (Van Houtum, 2002, 2010b). That is, the demarcation of Borders in space, often is co-incided with the making of an internal Order and is co-constituted with the making of Others. On the other side of the continuum there is what Deleuze and Guattari framed as 'psychoid desire', or what Nietzsche termed 'Dionysus'. Within this desire, there is longing for the Other side, the there. To actively want to escape the homogenising tendencies within the own B/Order and engage with and dwell in the differences across and outside the border. We argue that this epistemological two-sidedness of a border, this intrinsic ambivalence and ambiguity, renders a fertile ground for a thinking of design scenarios.

\section{Border as a mise-en-scene}

We developed three design strategies for designing the borderscape. Besides 'doing nothing', the study examined a 'radical dissolution of the border' option (Community scenario) and a 'strengthen the border in a theatrical manner' option (Desire scenario). These scenarios allow the border to be not only the cause of the present landscape, but also to set the imagination in motion and underpin visions of what the landscape might look like. For example, how can wishes or desires be given spatial expression? How can you design for the friction between the various interests in the area? These are questions and exercises that have relevance not only for the border landscape, but also for all forms of designing for borders.

\section{Autonomous development scenario}

A first option is no development of the border landscape. This non-development and non-design implies allowing room for endogenous development in the border landscape and the borderland. The advantage of this is that the border is truly opened up for a new appreciation, a new vision and new interpretations. A possible disadvantage is that the agoraphobia, the fear of the emptiness, and fear of lack of control, which is an important motivation for closing the border, may persist. As a consequence, the open space of such a non-development could become a no man's land. This could be liberating, but it could also drive a wedge between those on either side of the border.

So this scenario sketches what the border landscape would look like if national policies and the EU funded cross-border cooperation programme remain more or less the same. The original intermediaries - the Euregions - gradually evolve into institutions with an interest in maintaining the status quo. The consequence of this is that while parties on both sides of the border apply jointly for subsidies, they then use them for their own purposes. If the current situation continues, there will continue to be no cross-border integrated spatial plans. Cooperation will remain limited to sectorial issues such as recreational infrastructure, regional promotion, education, healthcare, culture, water management and the construction and upgrading of infrastructure. At the national level, us/them thinking will persist and an area's importance will be measured against national criteria. The differences in planning culture will also remain.

\section{Community scenario}

In this design scenario, which is inspired on the Apollonian desire of European homogeneity, the importance of national borders become less relevant. The borders continue to exist, but the differences between the two sides have increasingly little to do with national characteristics, interests and policies. The regions themselves decide what is good for them. Allocation inefficiencies (such as double infrastructure, hospitals on both sides of the border) are sorted out and network optimisation supports sustainable regional development. The housing and employment markets are the first to become fully integrated. Spatial planning also becomes increasingly coordinated and gradually converged in overlapping circles. National policies and plans are revised in line with common regional interests and there is a dialogue between national principles. The particular qualities of the border landscape are treated pragmatically - as part of the sectorial policies for culture, tourism, nature conservation and recreation. The Euregions are concerned primarily with optimising the natural 


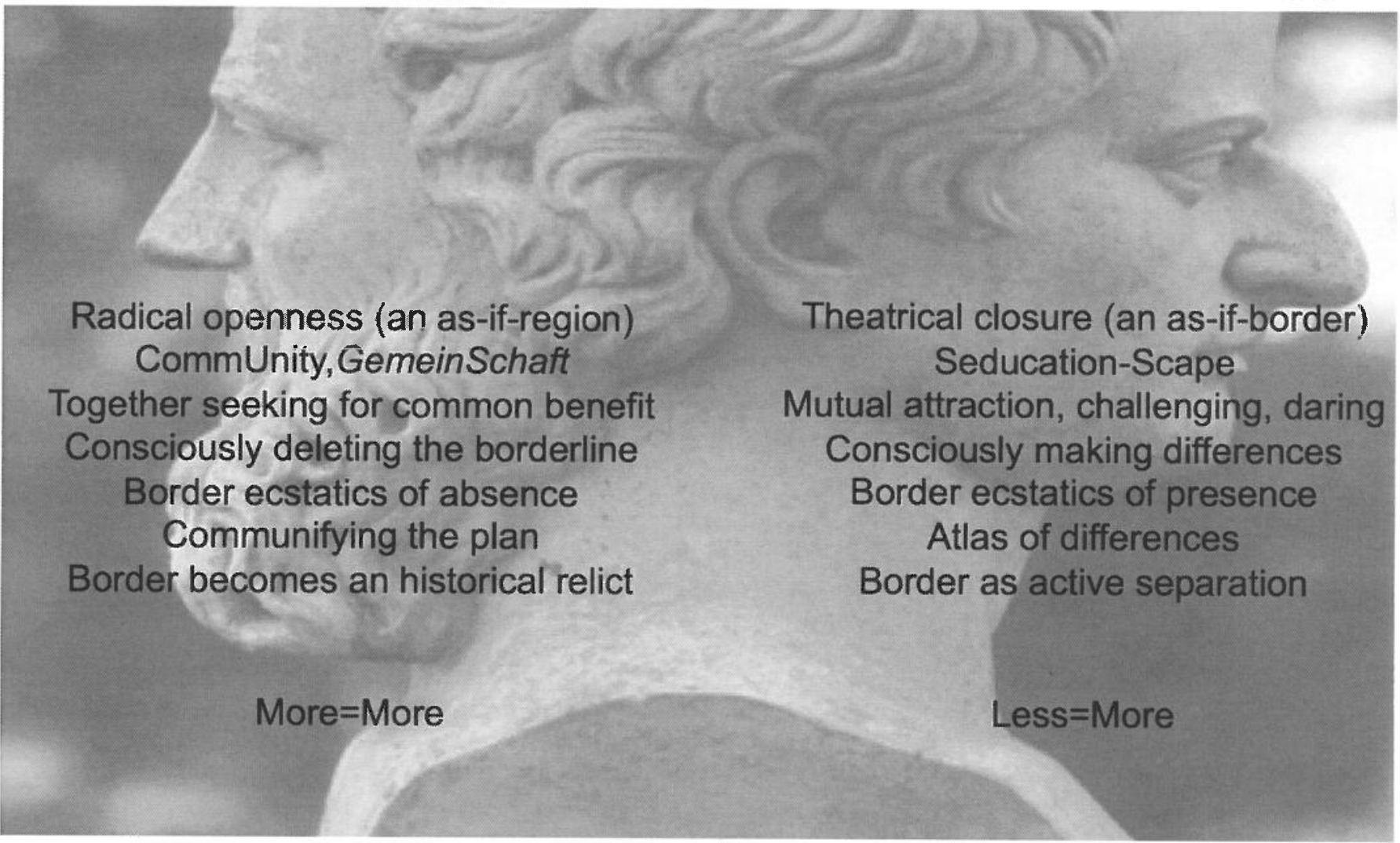


and economic infrastructure, which thus becomes increasingly the same on both sides of the border. The border becomes a cultural-historical relict.

\section{Desire scenario}

In this scenario the European Union and the national governments have discovered the potential of border landscapes as landscape and cultural showpieces and have made the creation of spatial differentiation in the border zone a national policy objective. Following decades of Euregional experimentation it has become clear that real interaction in the border landscape does not come about through attempts to build a sense of collective identity, because the effect on the ground is almost always mediocre. A much more promising strategy is to focus on the specific aspects of the border landscape, such as its two-sidedness and ambiguity. The regional differences in the landscape throw up a range of unique and interesting design challenges for the European border landscapes, which are testing grounds for instrumental physical planning and design. The planning and design of the border zone includes reflecting on the otherness of 'the other'. This perspective is inspired by the Dionysus desire. In landscape terms this does not mean that partners on both sides of the border try to meet each other's wishes or expectations, but rather that the aim is to create an interesting and distinctive border landscape that reflects shared qualities and goals. And offers peak and troughs, as seductive frames. Through speculative, playful themes and extravagant interventions, that illuminate the transformative and non-conflictual, resourceful potential of borderlands, researchers and designers can show how the physical landscape can be used to surprise, challenge, provoke, seduce and serve 'the other'.

The unexpected and unregulated parasitisation by 'the other side' of these unilateral interventions is a positive thing. Longing is bound up with transience, with coming and going - Heimweh und Fernweh. This feeling can be fed by manipulating space and time at the border, undoing and redoing the border; for example, selectively improving or restricting accessibility and in some places expanding the border into a 'border space' between the two nations. One way of encouraging movement across the border is to design housing facilities and landscapes for temporary use. In this scenario the Euregion is the guardian of differences and promotes the otherness of 'the other'.

\section{Dasein $^{3}$ is design}

The European Union has already made considerable investments in the creation of a transnational space, but this project does not seem to have struck deep roots. Numerous bridges have been built, but bridges have a tendency to disregard the underlying landscape. The border area itself, that which lies under the metaphorical bridge, remains undiscovered and untouched by both parties. With this study we hope to render new design for precisely this forgotten ground underneath those many and often heavily subsided metaphorical bridges that still creates planning enclosures. For, the problem of enclosure is not due to the border itself, but the traditional interpretation of the border, the conventional meaning given to it (Van Houtum, 2010a). The traditional idea of the border as the territorial limit of a country - the edgeland that serves to protect the heartland - still dominates our thinking. Two thousand years of Platonic geometric thinking has proved difficult to erase. So one could ask whether our persistent desire for national borders and the bounded fear of the other can be made more fluid, more an object to work with than see a border as an end by a new design policy for the border landscape? A revision of the border may well be insufficient to bring about a fundamental opening up of society, but it could be a start. Moreover, it is now within our grasp and there seems to be a chance of creating a fluid perspective, or, to borrow Henk Oosterling's expression, an 'inter-esse': a shift to a halfway area in which opportunities are created for the desire for an outside and an other, without the loss of familiarity and comfort. We can therefore use the border and the borderland as a micro situation, as an exercise in the dynamics between demarcation and boundlessness, a shadow dance of presence and absence. The borderland in the European Union waits patiently. It has been waiting for a new interpretation since the lifting of the internal borders. A revaluation of this borderland can be a driver for new development.

This 'policy vacuum' for the border itself as a territory should be seized upon as the subject of a new dialogue between people and the physical environment. We should make something of the relationship between people and the border landscape, their territorial fears, uncertainties and desires. This requires an alternative vision of the landscape that is the border. Precisely because giving substance to the closed or open character of the border depends on human interpretation, the border itself creates the room for reinterpretation. We need a vision of the landscape that will emerge when the border is re-evaluated, not as a driver for change, but as a generator of ideas for a new interpretation of the border. The emptiness of the border now expresses distance, fear and uncertainty, a vacuum between the here-land and the there-land. It is this vacuum that offers room for reinterpretation.

It is time, and there is room, for a turnaround in which the border is seen not as the terminus, but the departure point for a new development. After all, we are not only victims of the border. Borders do not only protect and exclude, they are also opportunities, and the periphery is also a beginning. Besides, we are the perpetrators of the border. Laying down a border is a strategic collaborative deed. The reality of a border therefore permits itself to be reformed or transformed, a process in which the border landscape can serve as a vehicle for new interpretations.

So we would argue that there is chance to use interventions in the landscape to stimulate a form of spatial development that imbues the border with a different symbolism, one which is not purely geometric and geopolitical. We feel that along side the theoretical debate on understanding geopolitical efforts to border, order and other, as this will continue, there is also a need to analytically explore and exploit the borderlands and to redesign the borders as to make the differences and the distinction between here and there and us and them more fluid. To this end, we must open up our rigid geometric thinking to the possibility of a play on lines, a 
choreography of the border, without the destructive or exclusive interpretation of the border. For, if we accept that policies for the border have landscape implications, we can then reason backwards: reshaping the landscape will in turn have implications for thinking about national policy. And if we accept the idea that the border can be interpreted differently, and borders can be imagined differently in our heads and projected differently on a map, as human design, this will create room for reinterpretation and re-imagination and redesign. Although the planning emptiness of the borderland may still have an important symbolic function, the lifting, negation and disappearance of the borders in the physical landscape of the European Union has created more room for reinterpretation. The mono-functional reality of the border is less forcefully dictated by its morphological manifestation, at least within the common physical space of the European Union, and this creates more room for overwriting or recoding that reality and constructing and representing other realities. The result is a fabrication of space, a new theatrum, or fabrica mundi. As opposed to the traditional notion of borders as the end of the open space, the end of the polis, the design notion of the border implies the initiation of an open space, a space that is open to reconstruction and revision. Or to play with Heidegger's famous term dasein, the new Dasein of borderlands is Design! And this is not a task for policy makers or rulers of our territories alone. What we need is co-makership and a sense of co-ownership in redesigning our borders. For, it is primarily up to us people ourselves, as social constructors and designers of our political space, be in it the form of academics, entrepreneurs, citizens, artists or planners, to come up with new representations and imaginaries and semiotic meanings of borderscapes.

\section{Acknowledgements}

For this article excerpts from our book: Eker and Van Houtum, 2013, «Borderland: Atlas, essays and design. History, and future of the border landscape», have been used with permission.

\section{Notes}

1. Interreg initiative provides funding for interregional cooperation across Europe. It is implemented under the European Community's territorial co-operation objective and financed through the European Regional Development Fund (Erdf). Source: www.interreg4c.eu/programme/

2. Buoli, forthcoming, Border/Scaping, Envisioning the Moroccan Spanish Landscapes from a Borderlands Design Perspective, Doctoral
Dissertation, Politecnico di Milano.

3. In Heidegger's thinking the manifold notion of Dasein (Da-sein: there-being) indicates the distinctive mode of Being realized by human beings in time and space - i.e. a way of living shared by the members of a community (cfr. Heidegger, 1962).

\section{References}

Brambilla C., 2014, "Exploring the Critical Potential of the Borderscapes Concept», Geopolitics (www.tandfonline.com/doi/abs/10.10 80/14650045.2014.884561, last accessed 31/12/2014).

Brambilla C., Van Houtum H., 2012, «The Art of Being a Grenzgänger in the City of Berlin», Agorà, n. 4 special issue Borderscapes, pp. 28-31 (www.agora-magazine.nl/wp-content/uploads/2012/10/20124-Grensgänger-in-Berlin.pdf, last accessed 31/12/2014).

De Boer S., ed., 2007, Grenzgänger Tussen Disciplines. Over Jacques Rancière. Tekst \& Context, Valiz, Amsterdam.

Deleuze G., Guattari F., 2004, Anti-Oedipus. Vol. 1 of Capitalism and Schizophrenia, Continuum, London/New York (transl. Deleuze G. and Guattari F., 1972, Anti-Oedipe. Les Editions de Minuit, Paris).

Deleuze G., Guattari F., 2004, A Thousand Plateaus. Vol. 2 of Capitalism and Schizophrenia, Continum, London/New York (Lransl. Deleuze G. and Guattari F., 1980, Milles Plateaux, Les Editions de Minuit, Paris).

Eker M., Van Houtum H., 2013, Borderland: Atlas, Essays and Design. History and Future of the Border Landscape, Blauwdruk, Wageningen. Heidegger M., 1962, Being and Time, Harper \& Row, London.

Houtum van H., Spierings B., 2012, "Inleiding», Agorà, n.4 special issue Borderscapes, pp. 4-5 (www.agora-magazine.nl/losse-artikelen/ borderscapes-inleiding-2/; last accessed 31/12/2014).

Houtum van H., Van Naerssen T., 2002, «Bordering, Ordering and Othering», Tijdschrift voor Economische en Sociale Geografie (Tesg), vol. 93, n. 2, pp. 125-136. Doi: 10.1111/1467-9663.00189.

Houtum van H., Kramsch O.T., Zierhofer W., eds., 2005, B/ordering Space, Ashgate, London.

Houtum van H., 2010a, "Waiting Before the Law; Kafka on the Border», Social and Legal studies, vol. 19, n. 3, pp. 285-297. Doi: $10.1177 / 0964663910372180$.

Houtum van H., 2010b, "Human Blacklisting: The Global Apartheid of the EU's External Border Regime», Environment and Planning D: Society and Space, vol. 28, n. 6, pp. 957-976. Doi: 10.1068/d1909.

Nietzsche F., 1987, De geboorte van de tragedie, International Theatre Bookshop, Amsterdam (transl. Nietzsche F., 1872, Die Geburt der Tragödie).

Paasi A., 2005, "Generations and the 'Development' of Border Studies», Geopolitics, vol. 10, n. 4, pp. 663-671. Doi: 10.1080/14650040500318563.

Rajaram P.K., Grundy-Warr C., eds., 2007, Borderscapes: Hidden Geographies and Politics at Territory's Edge, University of Minnesota Press, Minneapolis.

Wilson T.M., Donnan H., 2012, "Borders and Border Studies" in Id. (eds.), A Companion to Border Studies, Wiley-Blackwell, London. 
Rivista trimestrale del Dipartimento
FrancoAngeli

ISSN $1825-8689$

$€ 17,50 \mathrm{ii}$ (R23. 2015.72]

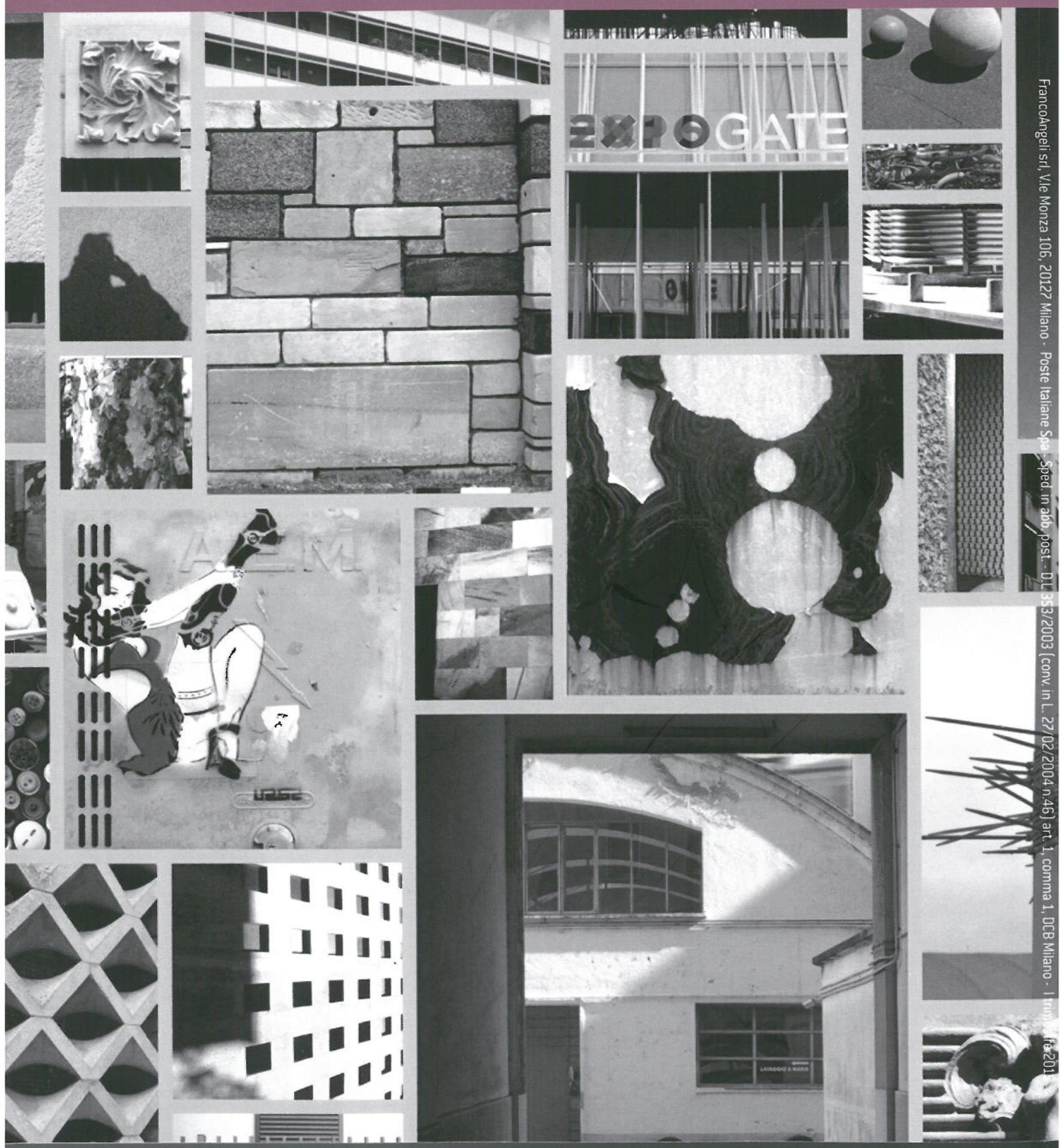

